\title{
Immortalized Human Dorsal Root Ganglion Cells Differentiate into Neurons with Nociceptive Properties
}

\author{
Heather K. Raymon, ${ }^{1}$ Silke Thode, ${ }^{1}$ Jiuying Zhou, ${ }^{1}$ Glenn C. Friedman, ${ }^{1}$ Jose R. Pardinas, ${ }^{1}$ Christian Barrere, ${ }^{1}$ \\ Randolph M. Johnson, ${ }^{2}$ and Dinah W. Y. Sah ${ }^{1}$ \\ 1Signal Pharmaceuticals Incorporated, San Diego, California 92121, and 2Roche Bioscience, Palo Alto, California 94304
}

\begin{abstract}
A renewable source of human sensory neurons would greatly facilitate basic research and drug development. We had established previously conditionally immortalized human CNS cell lines that can differentiate into functional neurons (Sah et al., 1997). We report here the development of an immortalized human dorsal root ganglion (DRG) clonal cell line, HD10.6, with a tetracycline-regulatable $\mathrm{v}$-myc oncogene. In the proliferative condition, HD10.6 cells have a doubling time of $1.2 \mathrm{~d}$ and exhibit a neuronal precursor morphology. After differentiation of clone HD10.6 for $7 \mathrm{~d}$ in the presence of tetracycline, v-myc expression was suppressed, and $>50 \%$ of the cells exhibited typical neuronal morphology, stained positively for neuronal cytoskeletal markers, and fired action potentials in response to current injection. Furthermore, this cell line was fate-restricted
\end{abstract}

to a neuronal phenotype; even in culture conditions that promote Schwann cell or smooth muscle differentiation of neural crest stem cells, HD10.6 differentiated exclusively into neurons. Moreover, differentiated HD10.6 cells expressed sensory neuron-associated transcription factors and exhibited capsaicin sensitivity. Taken together, these data indicate that we have established an immortalized human DRG cell line that can differentiate into sensory neurons with nociceptive properties. The cell line HD10.6 represents the first example of a human sensory neuronal line and will be valuable for basic research, as well as for the discovery of novel drug targets and clinical candidates.

Key words: sensory neuron; pain; PNS cell line; precursor; DRG; human
Nociceptive sensory neurons of the dorsal root ganglion (DRG) are activated by painful or noxious stimuli in the periphery and transmit this information to the CNS. The highly specialized functions of these neurons are subserved by distinct combinations of molecular and cellular properties, some of which are unique to nociceptive neurons. These characteristics include the expression of capsaicin receptors (Fitzgerald, 1983; Bevan et al., 1987; Szallasi, 1994; Caterina et al., 1997), tetrodotoxin (TTX)resistant sodium channels (Kostyuk et al., 1981; Caffrey et al., 1992; Roy and Narahashi, 1992; Elliott and Elliott, 1993; Ogata and Tatebayashi, 1993; Akopian et al., 1996; Sangameswaran et al., 1996), P2X3 purinoceptors (Chen et al., 1995; Lewis et al., 1995), sustained proton-gated current (Bevan and Yeats, 1991; Zeilhofer et al., 1996; Waldmann et al., 1997a,b), neuropeptides (Hunt and Rossi, 1985; Holzer, 1988) such as substance P and calcitonin gene-related peptide, TrkA receptors (Molliver et al., 1995), and c-Ret/glial cell line-derived neurotrophic factor receptors (GDNFR)- $\alpha$ (Molliver et al., 1997).

Although these properties have been elucidated in primary DRG cultures, such cultures contain relatively few neurons and are not easily transfectable with exogenous genes. These limita-

\footnotetext{
Received Nov. 30, 1998; revised April 15, 1999; accepted April 16, 1999.

We thank Drs. David J. Anderson, Fred H. Gage, Steve Heinemann, Patrick Hogan, Bruce Koch, Steve Matsumoto, Mahendra S. Rao, Jacqueline A. M. Smith, A. Neil Verity, and John N. Wood for suggestions during the course of this work and Drs. David W. Anderson and Alan Lewis for encouragement. We also thank Michael Housley, Hoang Le, James Leisten, Nandita Patnaik, and Gilbert Ramirez for outstanding technical support and Nathan Eller for expert graphics assistance.

Correspondence should be addressed to Dr. Heather K. Raymon, Signal Pharmaceuticals Incorporated, 5555 Oberlin Drive, Suite 100, San Diego, CA 92121.

Dr. Johnson's present address: DURECT Corporation, 10240 Bubb Road, Cupertino, CA 95014.

Dr. Sah's present address: Biogen, 14 Cambridge Center, Cambridge, MA 02142. Copyright (C) 1999 Society for Neuroscience $0270-6474 / 99 / 195420-09 \$ 05.00 / 0$
}

tions, which are prohibitive for many biochemical and molecular studies, can be overcome with immortalized cell lines that differentiate readily into sensory neurons. Such cell lines will facilitate the identification and validation of new targets for the treatment of pain, as well as the study of mechanisms regulating sensory neuron differentiation, maturation, and survival.

We report here the establishment of a stable immortalized clonal human DRG cell line that differentiates into neurons with nociceptive properties. These properties include expression of the sensory neuron-selective transcription factor DRG11 (Saito et al., 1995), sensitivity to capsaicin, and expression of a sustained proton-gated current. Furthermore, using this cell line, we examined the relative importance of extrinsic versus intrinsic determinants in sensory neuron differentiation. Although previous reports had suggested that peripheral neural progenitors undergo progressive restrictions in developmental potential, the existence of committed sensory neuronal progenitors in the DRG was controversial. The immortalization of a fate-restricted sensory neuronal progenitor from human DRG establishes the existence of such progenitor cells. The human cell line described here represents the first example of a stable immortalized DRG cell line that gives rise to neurons with nociceptive properties.

\section{MATERIALS AND METHODS}

Primary cell culture. Human DRGs from first trimester embryos were dissected and maintained for $\sim 48 \mathrm{hr}$ at $4^{\circ} \mathrm{C}$ before dissociation. Ganglia were dissociated by incubation at $37^{\circ} \mathrm{C}$ for $20 \mathrm{~min}$ in an enzyme solution containing $1 \mathrm{mg} / \mathrm{ml}$ collagenase (type 4; Worthington, Freehold, NJ) and $4 \mathrm{mg} / \mathrm{ml}$ dispase (grade II; Boehringer Mannheim, Indianapolis, IN) with occasional trituration. The cell suspension was washed twice with L15 medium and subsequently plated on a fibronectin (Life Technologies, Gaithersburg, MD) substrate in L15 complete medium [L15-C; based on Stemple and Anderson (1992)] with $40 \mathrm{ng} / \mathrm{ml} \mathrm{FGF-2} \mathrm{(human}$ recombinant basic fibroblast growth factor; Boehringer Mannheim). 
Immortalization. Cultures were immortalized with the retroviral vector LIN X v-myc, using methods similar to those described previously (Sah et al., 1997). In this system, expression of the v-myc oncogene is controlled by a tetracycline-sensitive transactivator that binds to a minimal cytomegalovirus promoter in the absence of tetracycline, driving transcription of the oncogene. Tetracycline $(0.01-1.0 \mu \mathrm{g} / \mathrm{ml}$; Sigma, St. Louis, MO) almost completely abolishes transcriptional activation by the tetracycline-sensitive transactivator, thereby blocking transcription of the $\mathrm{v}-m y c$ oncogene. A gene conferring neomycin resistance is also present in the vector, permitting selection of infected cells by exposure to G418 (100-200 $\mu \mathrm{g} / \mathrm{ml})$.

Expansion and passaging of immortalized cultures. After retroviral infection and G418 selection, human DRG cultures were expanded. Cultures approaching confluency were passaged by trypsinization and typically replated at $7 \times 10^{3}$ cells $/ \mathrm{cm}^{2}$.

Isolation of clonal cell lines. Clones were isolated by limiting dilution in 96-well plates. Cultures were maintained and passaged as described above.

Genomic Southern blot analysis. Total DNA was prepared from $\sim 1.5 \times$ $10^{6}$ cells using standard methods and was digested with restriction enzymes that cut in the integrated provirus (BamHI, EcoRI, BstEII, or HindIII; New England Biolabs, Beverly, MA). The digested DNA was resolved on a $0.8 \%$ agarose gel, transferred to a nylon membrane, and hybridized to a random-primed ${ }^{32} \mathrm{P}$-labeled Pst $\mathrm{I}-P s t \mathrm{I}$ fragment from MC29 virus that contains v-myc (Lofstrand Labs Limited, Gaithersburg, MD).

Differentiation of immortalized cultures and clonal cell lines. For differentiation, immortalized cells were plated onto polyornithine- and laminin-coated tissue culture plastic and then switched to differentiation medium. The differentiation medium consisted of L15-C (without chick embryo extract or FGF-2) or Ultraculture medium (BioWhittaker, Walkersville, MD) plus tetracycline $(1 \mu \mathrm{g} / \mathrm{ml})$. In addition, the following factors were included in the differentiation medium alone or in combination: human serum $(2.5 \%)$, fetal bovine serum $(10 \%)$, retinoic acid $(0.5$ $\mu \mathrm{M})$, forskolin $(5-10 \mu \mathrm{M})$, GDNF (25 ng/ml; Promega, Madison, W I), CNTF (25 ng/ml; R \& D Systems, Minneapolis, MN), NGF (25 ng/ml; $\mathrm{R} \& \mathrm{D}$ Systems), and heregulin $\beta 1$ ( $80 \mathrm{ng} / \mathrm{ml}$; R \& D Systems). In some differentiation experiments, tetracycline was added to the proliferation medium, which also contained epidermal growth factor (EGF; $100 \mathrm{ng} / \mathrm{ml}$; Life Technologies), FGF-2 (4 ng/ml; Boehringer Mannheim), and NGF (20 ng/ml; R \& D Systems). In a few experiments, cells were differentiated on the fibronectin substrate.

Immunofluorescence. Cultures were fixed and stained using methods described previously (Sah et al., 1997). Representative fields from at least two independent experiments were imaged using a Photometrics Sensys 12-bit digital camera and IPLAB Spectrum imaging software and then were scored. 4',6-Diamidino-2-phenylindole (DAPI) counterstaining of nuclei was used to determine the total number of cells within a field. Primary antibodies used for immunofluorescent detection included polyclonal antibodies against glial fibrillary acidic protein (GFAP; Chemicon, Temecula, CA), substance P (Chemicon), TrkA (Santa Cruz Biotechnology, Santa Cruz, CA), TrkC (Santa Cruz Biotechnology), tyrosine hydroxylase (TH; Chemicon), and v-myc (Caltag, South San Francisco, CA) and monoclonal antibodies against Islet-1 (Developmental Hybridoma Bank, Iowa City, IA), NF160 (Sigma), p75 (clone 8211; Accurate Chemicals, Westbury, NY), peripherin (Chemicon), and $\beta$-III tubulin (Sigma). Secondary antibodies (Jackson ImmunoResearch, West Grove, PA) used for immunofluorescent detection were donkey anti-mouse antibodies conjugated to Texas Red or $\mathrm{Cy} 3$ and donkey anti-rabbit antibodies conjugated to FITC or Cy3. The specificity of all primary and secondary antibodies was confirmed on appropriate positive and negative control cultures.

Cobalt histology. Cobalt histology was performed as described previously (Wood et al., 1988) with the following slight modification. The cells were exposed to Ringer's solution containing $1 \mu \mathrm{M}$ capsaicin and $10 \mathrm{~mm}$ $\mathrm{CoCl}_{2}$ for $8 \mathrm{~min}$ in the presence or absence of the antagonist capsazepine $(10 \mu \mathrm{M})$. After histological processing, cultures were coverslipped with polyvinyl alcohol and 1,4-diazabicyclo[2,2,2]octane.

$P C R$. mRNA was extracted from tissue samples and frozen cell pellets using the MicroFastTrack kit (Invitrogen, San Diego, CA) according to the manufacturer's protocol. The RNA was then reverse transcribed using the cDNA Cycle kit (Invitrogen). Non-reverse-transcribed control samples were generated by omitting the AMV reverse transcriptase. One microliter of cDNA template was amplified in a total reaction volume of $100 \mu \mathrm{l}$ containing $10 \mathrm{~mm}$ Tris $\mathrm{HCl}, \mathrm{pH} 8.3,50 \mathrm{~mm} \mathrm{KCl,} 1.5 \mathrm{~mm} \mathrm{MgCl}_{2}$,
5 units of Taq polymerase (Boehringer Mannheim), each analytical primer at $0.5 \mu \mathrm{M}$, each internal control primer at $0.1 \mu \mathrm{M}$, and each dNTP at $0.2 \mathrm{~mm}$. Amplifications using DRG11 primers included each RPL27 control primer at $0.1 \mu \mathrm{M}$ in the same reaction using the following conditions: initial denaturation for $2 \mathrm{~min}$ at $94^{\circ} \mathrm{C}$ and 35 cycles of $94^{\circ} \mathrm{C}$ for $30 \mathrm{sec}, 60^{\circ} \mathrm{C}$ for $30 \mathrm{sec}$, and $72^{\circ} \mathrm{C}$ for $1 \mathrm{~min}$ followed by a final elongation step of $7 \mathrm{~min}$ at $72^{\circ} \mathrm{C}$. Amplifications using human achaete-scute homolog-1 (hASH1) primers were performed with an initial denaturation for $2 \mathrm{~min}$ at $94^{\circ} \mathrm{C}$ and 40 cycles of $94^{\circ} \mathrm{C}$ for $30 \mathrm{sec}$ and $72^{\circ} \mathrm{C}$ for 1.5 min followed by a final elongation step of $7 \mathrm{~min}$ at $72^{\circ} \mathrm{C}$. In this case, reactions with each RPL27 control primer at $0.1 \mu \mathrm{M}$ were done separately with an initial denaturation for $2 \mathrm{~min}$ at $94^{\circ} \mathrm{C}$ and 40 cycles of $94^{\circ} \mathrm{C}$ for 30 $\mathrm{sec}, 60^{\circ} \mathrm{C}$ for $30 \mathrm{sec}$, and $72^{\circ} \mathrm{C}$ for $1 \mathrm{~min}$ followed by a final elongation step of $7 \mathrm{~min}$ at $72^{\circ} \mathrm{C}$. Reaction products were resolved on 2-3\% agarose gels in Tris-borate and EDTA. Analytical restriction digests were used to confirm the specificity of the products.

Primer sequences were as follows: RPL27 forward (F), GAACATTGATGATGGCACCTC; RPL27 reverse (R), GGGGATATCCACAGAGTACC; hASH1 F, TTCAGCGGCTTTGGCTACAG; hASH1 R, GAGATGGTGGGCGACAGGAC; DRG11 F, ACCAGGAACCAGGGGCTAAGGA; and DRG11 R, GACGGCAGAAGGTTGGCAGACT.

Electrophysiology. Whole-cell recording was performed as described in Sah et al. (1997) with slight modifications. For recording action potentials as well as sodium and potassium currents, the external solution was $2 \mathrm{~mm}$ $\mathrm{Ca}^{2+}$ Tyrode's solution containing $150 \mathrm{mM} \mathrm{NaCl}, 4 \mathrm{~mm} \mathrm{KCl}, 2 \mathrm{~mm}$ $\mathrm{MgCl}_{2}, 10 \mathrm{~mm}$ glucose, and $10 \mathrm{~mm}$ HEPES, pH 7.4 with $\mathrm{NaOH}$, with 2 $\mathrm{mM} \mathrm{CaCl}{ }_{2}$ added. Action potentials were elicited by current injection with the internal solution containing $130 \mathrm{mM} \mathrm{KCl}, 5 \mathrm{mM} \mathrm{MgCl}_{2}, 10 \mathrm{~mm}$ EGTA, and $10 \mathrm{~mm}$ HEPES, pH 7.4 with KOH. Potassium currents were also recorded with this potassium chloride-based internal solution as well as $1 \mu \mathrm{M}$ TTX in the external solution to block sodium currents. For isolating voltage-gated sodium currents, cesium-containing internal solution was used to block voltage-gated potassium currents. Voltage-gated sodium and calcium currents and ligand-gated currents were recorded with an internal solution containing $108 \mathrm{~mm}$ cesium-methanesulfonate, 4 mм $\mathrm{MgCl}_{2}$, 9 mм EGTA, 9 mм HEPES, and, in some cases, 4 mм ATP, $14 \mathrm{~mm}$ creatine phosphate (Tris salt), and 0.3 mM GTP (Tris salt), pH 7.4 with $\mathrm{CsOH}$. For recording calcium channel current, the external solution was $160 \mathrm{~mm}$ tetraethylammonium chloride (TEA-Cl) with $5 \mathrm{~mm} \mathrm{BaCl} 2$, $10 \mathrm{~mm}$ HEPES, pH 7.40 with TEA-OH, and $1 \mu \mathrm{M}$ TTX added. Proton currents were elicited with $2 \mathrm{mM} \mathrm{Ca}^{2+}$ Tyrode's external solution adjusted to $\mathrm{pH} 5.1$ containing 2-[N-morpholino]ethanesulfonic acid in place of HEPES. Responses to $\alpha \beta$-methylene-ATP (20 or $100 \mu \mathrm{M}$, diluted from $100 \mathrm{~mm}$ stock in $\mathrm{H}_{2} 0$; Research Biochemicals, Natick, MA) and capsaicin (1 $\mu \mathrm{M}$, diluted from $10 \mathrm{mM}$ stock in DMSO; Research Biochemicals) were elicited by applying agonist in Tyrode's solution containing 0.5 $\mathrm{mMCa}{ }^{2+}$.

\section{RESULTS}

\section{Immortalization of human DRG progenitors}

Human embryonic DRG cultures were infected with the tetracycline-regulatable v-myc oncogene, using methods similar to those described previously (Sah et al., 1997). After 3 d of G418 selection, clusters of 5-14 cells were present. These proliferating cells were polygonal in shape and phase-dark, exhibiting a morphology similar to that of rat neural crest stem cells (Stemple and Anderson, 1992).

\section{Characterization of retrovirally infected human DRG progenitors}

As expected, the majority of G418-resistant cells were immunoreactive for the v-myc oncoprotein, as determined relative to positive and negative controls run in parallel. The proliferative cultures were examined with immunocytochemical methods for expression of the cell type-specific markers $\beta$-III tubulin (neuronal precursor marker), p75 (the low-affinity NGF receptor; expressed by neural crest stem cells), and GFAP (Schwann cell marker). Only $\beta$-III tubulin immunoreactivity was present $(0.3 \pm$ $0.2 \%$ of the cells), suggesting that a small population of neuronal precursors had been immortalized. After differentiation for 1-1.5 
A

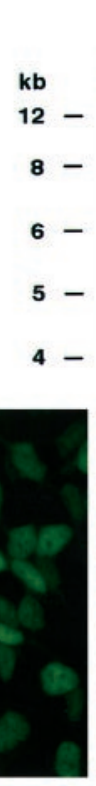

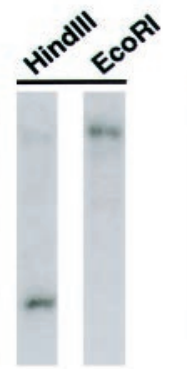

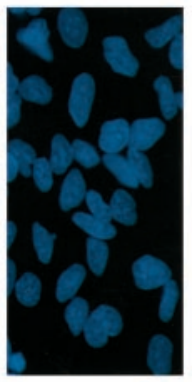

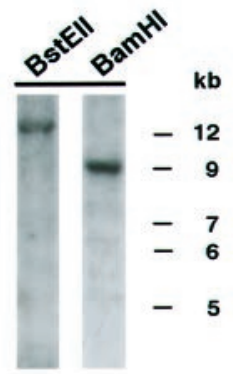
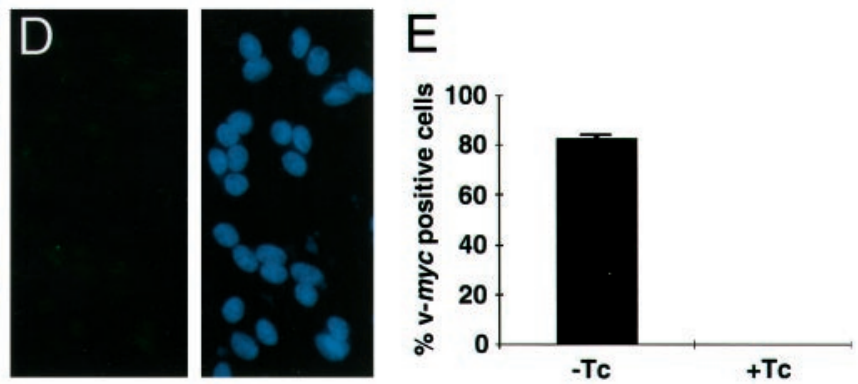

Figure 1. Clonal analysis and tetracycline suppression of v-myc immunoreactivity in the human DRG cell line HD10.6. $A$, Southern blot analysis of genomic DNA hybridized with a v-myc probe. The DNA was enzymatically digested with HindIII that cuts at two sites within the vector or with EcoRI, $B s t$ EII, or BamHI that cut within the vector and within the flanking DNA sequence. $B$, Phase contrast photomicrograph of HD10.6 cells grown in the proliferative condition. $C, D$, v-myc staining ( green, left) and DAPI counterstaining (blue, right) of cells grown in the proliferative growth condition without tetracycline $(C)$ and after $6 \mathrm{~d}$ of differentiation with tetracycline $(D)$. E. Histogram quantifying the percentage of cells immunoreactive for v-myc in the proliferative growth condition $(-T c)$ and after $6 \mathrm{~d}$ of differentiation with tetracycline $(+T c)$. Scale bars: $B, 30 \mu \mathrm{m} ; C, D, 30 \mu \mathrm{m}$.

weeks with tetracycline (Tc), human serum (HS), forskolin (Fsk), GDNF (G), CNTF (C), plus NGF (N) or with Tc, HS, retinoic acid (RA), G, C, plus N, the cultures contained cells that exhibited neuronal morphology (phase-bright, process-bearing) and $\beta$-III tubulin and NF160 immunoreactivities (as evaluated relative to positive and negative controls run in parallel), confirming that neuronal precursors had been immortalized.

\section{Isolation and expansion of clonal human DRG progenitor cell lines}

Clonal immortalized human DRG cell lines were isolated by limiting dilution. In some cases, putative clones were subcloned to insure clonality. One putative clone, HD10.6, that exhibited capsaicin sensitivity (see below) was the focus of the present study. To verify that HD10.6 arose from a single integration event and is clonal, genomic Southern analysis was performed. Genomic DNA from HD10.6 was digested with the restriction enzymes BamHI, EcoRI, BstEII, or HindIII and probed with $\left[{ }^{32} \mathrm{P}\right] \mathrm{v}-m y c$. As expected, HindIII produced a unit-length DNA fragment of $4.7 \mathrm{~kb}$, consistent with the absence of genetic rearrangement (Fig. 1A). BamHI, EcoRI, and BstEII each cut once within the provirus and at a unique site within the flanking genomic DNA; these restriction enzymes gave single bands (Fig. $1 A$ ) that were identical in early and late passage cultures, establishing that HD10.6 is clonal and stable with respect to the provirus integration site.

In the proliferative growth condition, clone HD10.6 exhibited a doubling time of $1.2 \mathrm{~d}$ and a morphology (Fig. $1 B$ ) similar to that described for neural crest-derived neuronal precursors isolated from the gut (Lo and Anderson, 1995).

Immunocytochemistry for v-myc confirmed the presence of the oncoprotein in HD10.6 cells and established that the oncoprotein was effectively downregulated by the addition of $\mathrm{Tc}$ to the growth medium. In the proliferative growth condition, $83 \pm 2 \%$ of HD10.6 cells expressed detectable v-myc immunoreactivity, with the staining confined to the nuclei as expected (Fig. 1C,E). In contrast, after $6 \mathrm{~d}$ of Tc treatment, no cells exhibited significant v-myc immunoreactivity (Fig. 1D,E).

\section{Neuronal differentiation of clone HD10.6}

Clone HD10.6 cells acquired neuronal morphology during differentiation on a polyornithine and laminin substrate in medium containing Tc, Fsk, HS, G, C, plus N (Fig. 2A). The time course of neuronal differentiation was rapid; phase-bright cells with rounded cell bodies and long processes were observed 3-4 d after the initiation of differentiation. Moreover, $\beta$-III tubulin, NF160, and peripherin immunoreactivities (Fig. $2 B-D$ ) were present in $61 \pm 8,46 \pm 5$, and $71 \pm 7 \%$ of differentiated HD10.6 cells, respectively.

To establish further the neuronal phenotype of clone HD10.6, we selected differentiated cells with neuronal morphology for electrophysiological recording. Regenerative action potentials were elicited by current injection (Fig. $3 A, 15$ of 15 cells). In contrast, proliferating HD10.6 cells were quiescent. Differentiated HD10.6 cells expressed a variety of voltage- and ligandgated currents exhibited by DRG neurons. Voltage-gated sodium current (Fig. 3B; $915 \pm 162 \mathrm{pA} ; n=12$ cells; holding potential of $-80 \mathrm{mV}$; test potential of $-10 \mathrm{mV}$ ) was rapid and blocked by 1 $\mu \mathrm{M}$ TTX (9 of 9 cells), indicating that all of the current was TTX-sensitive. Potassium current kinetics and voltage dependence were consistent with the delayed rectifier class of potassium currents (Fig. 3C), whereas calcium channel current kinetics and voltage dependence were consistent with the high-threshold class of calcium currents (Fig. $3 D ; 345 \pm 49 \mathrm{pA} ; n=7$ cells; holding potential of $-80 \mathrm{mV}$; test potential of $-10 \mathrm{mV}$ ). The cells expressed $\mathrm{P} 2 \mathrm{X}$ purinergic receptors, as indicated by their responses to $\alpha \beta$-methylene-ATP (20 or $100 \mu \mathrm{M}$ ) application with rapidly activating and desensitizing currents (Fig. 3E; $196 \pm 48$ $\mathrm{pA} ; n=6$ of 6 cells; holding potential of $-80 \mathrm{mV}$ ). In addition, 

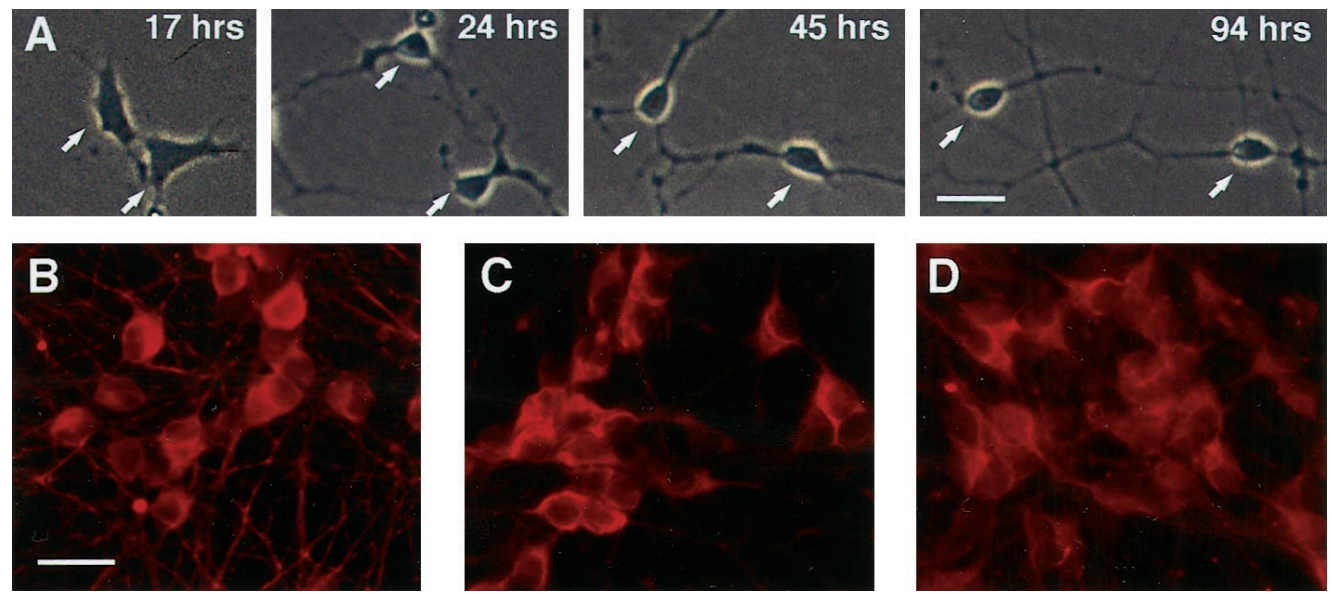

Figure 2. Neuronal differentiation of the HD10.6 cell line. $A$, Phase contrast photomicrographs of two cells at 17, 24, 45, and 94 hr after the start of differentiation are shown. $B-D$, Differentiated HD10.6 cells were immunoreactive for $\beta$-III tubulin $(B)$, NF160 $(C)$, and peripherin $(D)$. Scale bars: $A$, $30 \mu \mathrm{m} ; B-D, 20 \mu \mathrm{m}$.

the cells responded to application of acidic ( $\mathrm{pH} 5.1)$ solution with inward currents comprised of both transient (932 $\pm 284 \mathrm{pA} ; n=$ 7 of 7 cells $)$ and sustained $(121 \pm 29 \mathrm{pA} ; n=10$ of 12 cells $)$ components at $-80 \mathrm{mV}$ (Fig. $3 F$ ).

\section{Neuronal fate restriction of clone HD10.6}

To determine the relative importance of extrinsic versus intrinsic cues in fate determination, we differentiated clone HD10.6 in conditions that are instructive for the differentiation of neural crest stem cells into Schwann cells (Stemple and Anderson, 1992; Shah et al., 1994) or smooth muscle cells (Shah et al., 1996).

HD10.6 cells grown in the standard neuronal differentiation medium (Tc, HS, Fsk, G, C, plus N) stained positively for $\beta$-III tubulin and NF160 but not for GFAP or the smooth muscle marker calponin (Fig. 4). Similarly, cells differentiated with Tc plus heregulin $\beta 1$ (Fig. 4), with Tc, Fsk, plus fetal bovine serum (data not shown), with Tc plus transforming growth factor (TGF) $\beta 1$ (Fig. 4), or with Tc, EGF, basic fibroblast growth factor (FGF-2), NGF, plus chick embryo extract (data not shown) were $\beta$-III tubulin-immunoreactive but not GFAP- or calponinimmunoreactive. Although the proportion of $\beta$-III tubulinimmunoreactive cells was comparable in all of these conditions, the percentage of NF160-immunoreactive cells was considerably less in the heregulin $\beta 1$ and TGF $\beta 1$ conditions (Fig. $4 B$ ). This is most likely caused by an effect on the maturation of the neurons because weak NF160 labeling was observed (Fig. 4A). Nevertheless, these data indicate that clone HD10.6 differentiates into neurons regardless of the factors present in the culture medium.

After growth in the standard neuronal differentiation medium, two other clones, derived from the same original immortalized human DRG culture, gave rise to GFAP-immunoreactive Schwann cells and calponin-immunoreactive, elongated, multinucleated muscle cells. Therefore, under these conditions, immortalized precursor cells of other lineages will differentiate into non-neuronal cells. In contrast, HD10.6 cells differentiate only into neurons, independent of the differentiation conditions, and therefore appear to be committed neuronal progenitor cells.

Substrate also plays an important role in the differentiation of neural crest stem cells, with fibronectin inhibiting neuronal specification (Stemple and Anderson, 1992). To examine the effect of substrate on differentiation of clone HD10.6, we compared cultures during $6 \mathrm{~d}$ of differentiation on a polyornithine and laminin versus fibronectin substrate. On both substrates, cells with neuronal morphology were observed to a similar extent over the course of the differentiation period (data not shown). These results establish that clone HD10.6 is committed to a neuronal fate independent of growth factor and substrate conditions.

\section{Sensory neuronal lineage of clone HD10.6}

Neural progenitors in the DRG have been reported to differentiate into autonomic neurons (Schweizer et al., 1983; Le Douarin et al., 1985; Xue et al., 1988, 1992). To determine whether we had immortalized a sensory or autonomic neuronal progenitor, we examined clone HD10.6 for the expression of sensory- and autonomic-selective transcription factors and for a specific sympathetic neuronal enzyme. DRG11, a transcription factor specifically expressed in postmigratory sensory neurons but not in autonomic neurons or glia (Saito et al., 1995), was present after differentiation of HD10.6 (Fig. 5A). In contrast, hASH1, a transcription factor found only within autonomic precursors in the peripheral nervous system (Lo et al., 1991), was absent in proliferating and differentiated HD10.6 cells (Fig. 5B). Furthermore, differentiated HD10.6 cells did not express TH (Fig. 5C), a marker for sympathetic neurons from the autonomic lineage.

Additional sensory neuronal markers were present in differentiated HD10.6 cells. Substance P immunoreactivity was present in all differentiated HD10.6 cells with neuronal morphology (Fig. $6 A$ ), whereas Islet-1, a transcription factor required for DRG formation (Pfaff et al., 1996), was present in the nuclei of $\sim 50 \%$ of differentiated HD10.6 cells (Fig. $6 B$ ). In addition, all differentiated HD10.6 neurons were immunoreactive for TrkA (Fig. 6C) and p75 (Fig. 6D), but we were unable to detect significant levels of TrkC immunoreactivity. Taken together, these results suggest that clone HD10.6 belongs to the lineage of small-diameter, TrkA-immunoreactive sensory neurons.

\section{Capsaicin sensitivity of clone HD10.6}

Capsaicin sensitivity is a hallmark of nociceptive sensory neurons. To examine differentiated HD10.6 cells for capsaicin responsiveness, we used cobalt histology and electrophysiological recording. Thirty-two percent of differentiated HD10.6 neurons exhibited detectable levels of cobalt staining in response to $1 \mu \mathrm{M}$ capsaicin (Fig. 6E); this staining was blocked by $10 \mu \mathrm{M}$ capsazepine. Electrophysiological recordings from differentiated 

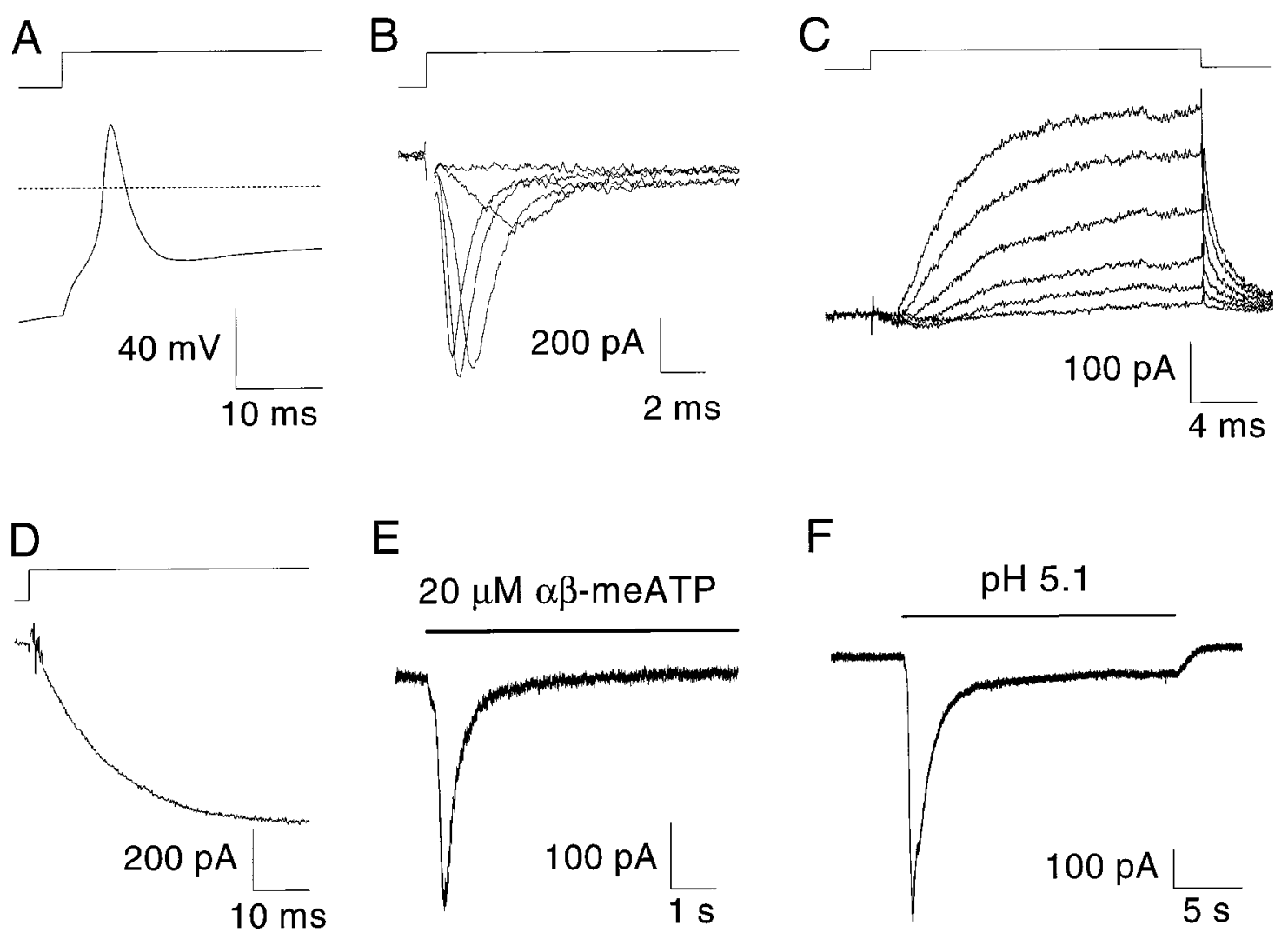

Figure 3. Action potential and voltage- and ligand-gated currents in neuronally differentiated HD10.6 cells. Current or voltage pulses are illustrated above the data traces in $A-D$. A, Action potential elicited by current injection (104 pA). Dashed line indicates membrane potential of $0 \mathrm{mV}$. $B$, Sodium currents elicited by depolarizations from a holding potential of $-80 \mathrm{mV}$ to test potentials of $-40,-30,-20,-10$, or $0 \mathrm{mV}$. Sodium currents were isolated using an internal solution containing cesium to block potassium currents. $C$, Potassium currents elicited by depolarizations from a holding potential of $-80 \mathrm{mV}$ to test potentials of $-30,-20,-10,0,+10$, or $+20 \mathrm{mV}$. Potassium currents were isolated by including $1 \mu \mathrm{M}$ TTX in the external solution to block sodium currents. $D$, Calcium channel current in response to depolarization from a holding potential of -80 to $-10 \mathrm{mV}$. $E$, $\alpha \beta$-Methylene-ATP $(\alpha \beta$-meATP) response elicited by applying $20 \mu \mathrm{M} \alpha \beta$-methylene-ATP (solid horizontal bar) for $7 \mathrm{sec}$ at a holding potential of $-80 \mathrm{mV}$. F, Proton-activated current elicited by applying an acidic (pH 5.1) solution (solid horizontal bar) for $30 \mathrm{sec}$ at a holding potential of $-80 \mathrm{mV}$.

HD10.6 neurons confirmed that the cells express functional capsaicin receptors (Fig. $6 F ; 1 \mu \mathrm{M}$ capsaicin; $423 \pm 96 \mathrm{pA} ; 11$ of 11 cells; holding potential of $-80 \mathrm{mV}$ ). These data show that differentiated HD10.6 cultures contain neurons with nociceptive properties.

\section{DISCUSSION}

We have established, for the first time, a stable immortalized clonal cell line that differentiates into sensory neurons with nociceptive features. The properties of this cell line indicate that sensory neuronal precursor cells exist in the human embryonic DRG. Furthermore, using this cell line, we showed that intrinsic determinants dominated the fate of the cell when challenged with different external stimuli. These data suggest that we have immortalized a human DRG progenitor cell after commitment to a sensory neuronal lineage.

Previous studies, using clonal analyses of primary cultures (Duff et al., 1991; Stemple and Anderson, 1992; Shah et al., 1994, 1996; Lo and Anderson, 1995), in vitro analysis of an immortalized cell line (Rao and Anderson, 1997), in vivo tracer injection (Bronner-Fraser and Fraser, 1988), retroviral marking (Frank and Sanes, 1991), and transplantation methods (Schweizer et al., 1983), have demonstrated the existence of multipotent and developmentally restricted precursor cells in the developing rodent and avian peripheral nervous systems. Specifically, these studies established that premigratory neural crest stem cells give rise to neurons as well as Schwann cells, smooth muscle cells, and melanocytes and that the fate of neural crest stem cells can be influenced by environmental signals in vitro (Matsumoto, 1994; Sun and Maxwell, 1994; Maxwell et al., 1996; Varley and Maxwell, 1996) and in vivo. However, less is known about the developmental capacity of postmigratory neural crest stem cells. In the gut, postmigratory neural crest stem cells committed to a neuronal lineage exist (Lo and Anderson, 1995). However, in the DRG, some reports suggest that a population of latent autonomic precursors is present (Schweizer et al., 1983; Le Douarin et al., 1985; Xue et al., 1988, 1992), whereas other studies (Duff et al., 1991) indicate that committed sensory neuronal precursors are present.

In the present study, the properties of the human DRG cell line HD10.6 suggest that human DRG progenitor cells undergo progressive restrictions in developmental potential, becoming faterestricted to a sensory neuronal lineage. HD10.6 cells differentiate only into neurons, even when grown in culture conditions that promote the differentiation of neural crest stem cells into Schwann cells or smooth muscle cells (Stemple and Anderson, 1992; Shah et al., 1994, 1996). Moreover, HD10.6 cells express the sensory neuron-selective transcription factor DRG11 but not the autonomic precursor-selective transcription factor hASH1. Because our immortalization approach requires cell division for 


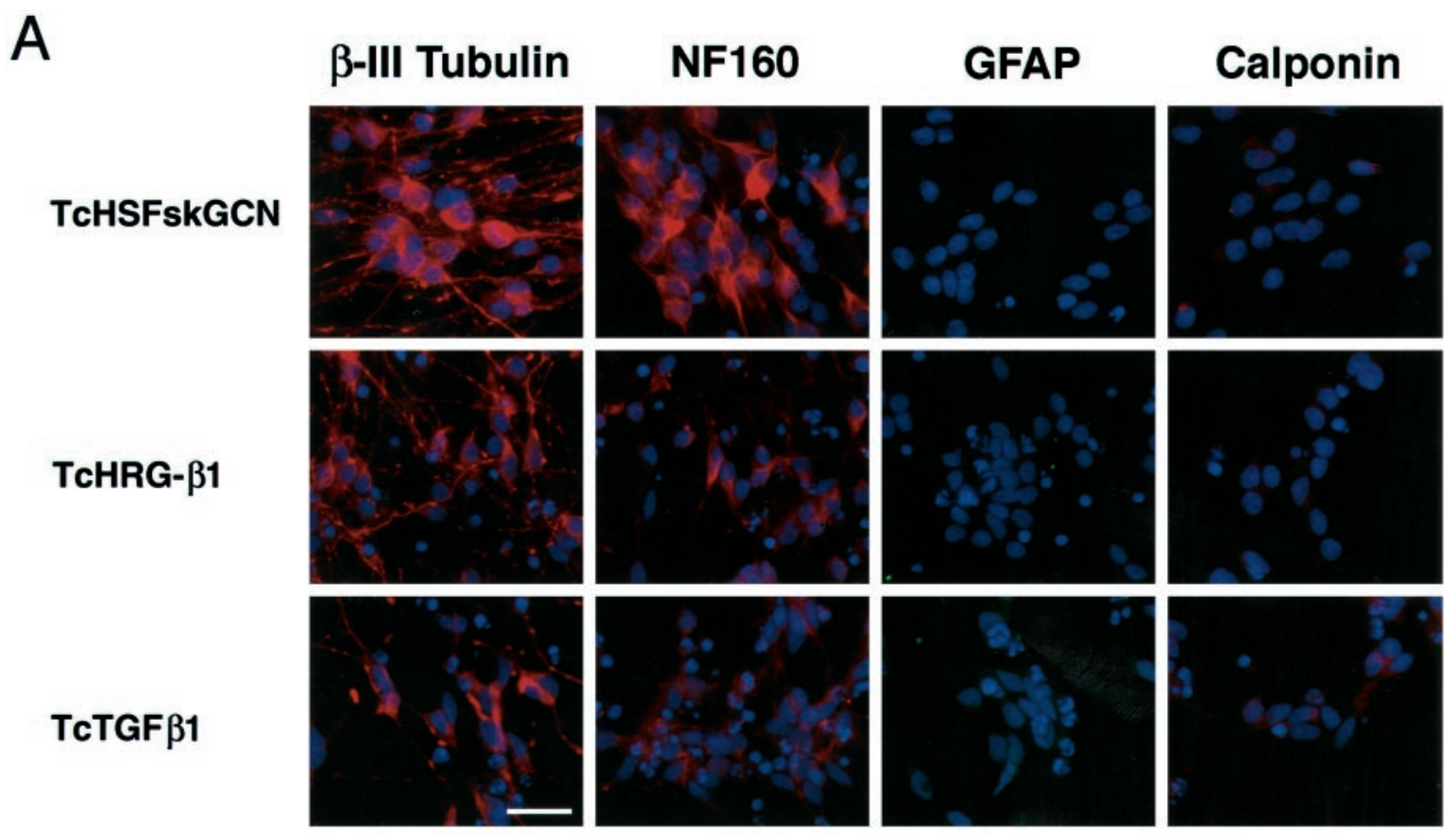

B

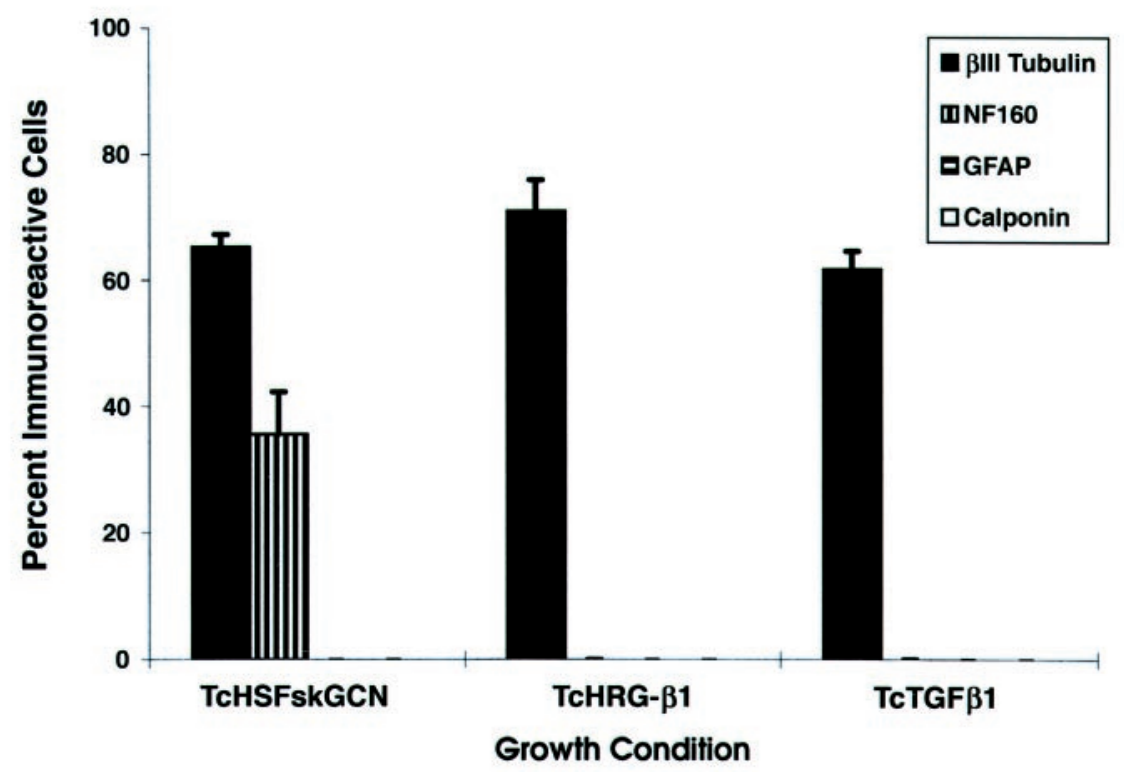

Figure 4. Restriction of HD10.6 cells to a neuronal fate. A, HD10.6 cells were grown for $5 \mathrm{~d}$ in Tc, HS, Fsk, G, C, plus N (TcHSFskGCN); Tc plus heregulin $\beta 1$ (TcHRG- $\beta 1$ ); or Tc plus TGF $\beta 1$ (TcTGF $\beta 1$ ). Cells were then immunostained for $\beta$-III tubulin, NF160, GFAP, or calponin. DAPI counterstaining reveals all the nuclei in the field. $B$, Quantitation of cell type-specific markers in HD10.6 cells shows the percentage of cells immunoreactive for $\beta$-III tubulin, NF160, GFAP, and calponin after differentiation with Tc, HS, Fsk, G, C, plus N; Tc plus heregulin $\beta 1$; or Tc plus TGF $\beta 1$. Scale bar, $30 \mu \mathrm{m}$.

successful retroviral infection, the properties of HD10.6 support the existence in the DRG of proliferative human progenitor cells that are committed to a sensory neuronal lineage. A possible caveat is that the DRG cells that initially gave rise to HD10.6 did not have the same fate restriction as HD10.6, as a result of immortalization and/or subsequent cell division. We addressed this issue by evaluating clone HD10.6 as soon as a sufficient number of cells was available and by comparing the behavior of
HD10.6 cells from an early passage with the behavior of HD10.6 cells from a later passage. HD10.6 cells exhibit a stable differentiated phenotype over $>65$ doublings, suggesting that fundamental changes in behavior do not occur after cell division and passaging. Therefore, we propose that unlike premigratory neural crest stem cells, committed human DRG progenitor cells exist that have lost the capacity to differentiate into multiple cell types and are restricted to a sensory neuronal fate. 

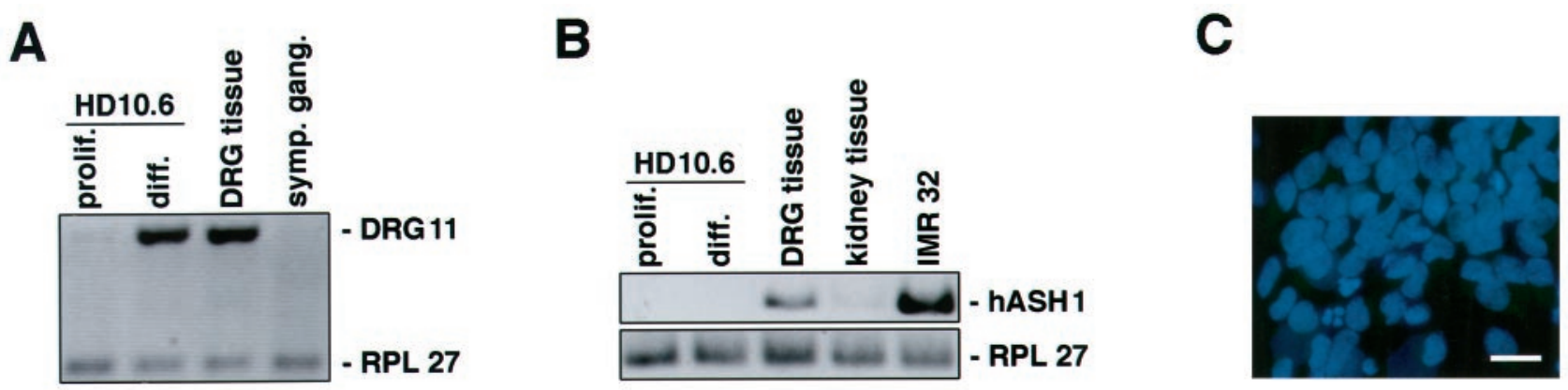

Figure 5. HD10.6 cells express features of sensory but not autonomic neurons. $A, B$, Reverse transcription-PCR analysis of DRG11 $(A)$ and hASH1 $(B)$ expression in HD10.6 cells after growth in proliferative ( prolif.) or differentiating (diff.) conditions. Negative controls are sympathetic ganglia (symp. gang.; $A$ ) and kidney tissue $(B)$. Positive controls are human DRG tissue $(A)$ and IMR 32 cells $(B)$. $C$, Lack of tyrosine hydroxylase immunoreactivity (green) in differentiated HD10.6 cells, with DAPI counterstaining (blue) to reveal all nuclei in the field. Scale bar, $20 \mu \mathrm{m}$.

Differentiated HD10.6 cells exhibit a number of properties characteristic of sensory neurons, including neuronal cytoskeletal markers, transcription factors, neurotransmitters, ion channels, and neurotransmitter receptors. As expected, $\beta$-III tubulin, NF160, peripherin, substance $\mathrm{P}$, Islet-1, TrkA, and $\mathrm{p} 75$ are present in these cells. Although these properties are also expressed in autonomic neurons, the expression of these characteristics in differentiated HD10.6 neurons, together with the sensory neuron-selective transcription factor DRG11, is consistent with a sensory neuronal phenotype.

As expected, differentiated HD10.6 neurons are functional, firing action potentials after current injection and expressing sodium, potassium, and calcium currents. Importantly, differentiated HD10.6 cells exhibit two distinctive features of nociceptors-capsaicin-activated current and sustained protonactivated current. Capsaicin has been shown to open cationic channels in the nociceptive subpopulations of mammalian sensory neurons that are associated with the $\mathrm{C}$ - and $\mathrm{A} \delta$-fibers (Bevan and Szolcsanyi, 1990). Although all differentiated HD10.6 neurons exhibit capsaicin $(1 \mu \mathrm{M})$-activated currents as assessed by electrophysiological measurements, only one-third of the neurons were labeled by the same concentration of capsaicin using cobalt histology. The dose of capsaicin $(1 \mu \mathrm{M})$ that we used is specific for nociceptors; the reported $\mathrm{EC}_{50}$ value for capsaicin-activated current is $0.2 \mu \mathrm{M}$, with maximal responses elicited by $1 \mu \mathrm{M}$ capsaicin (Wood et al., 1988). Wood et al. (1988) also showed that with cobalt histology, $1 \mu \mathrm{M}$ capsaicin selectively labeled the nociceptive subpopulation of DRG neurons in culture, which represented $50 \%$ of the cells, but not other peripheral neurons or nonneuronal cells. A possible explanation for the discrepancy that we observed between electrophysiological and histological assessments of the presence of capsaicin receptors is the lower sensitivity of the histological approach. Electrophysiological measurements directly measure the presence of functional capsaicin receptors and are sensitive enough to detect a single channel, whereas the histological approach is indirect and of unknown sensitivity. Therefore, our conclusion is that all differentiated HD10.6 neurons express capsaicin receptors, as indicated by the electrophysiological measurements. Sustained proton-activated current represents an additional property selectively expressed in nociceptors because it has been reported to be present only in sensory neurons of small diameter that respond to capsaicin (Bevan and Yeats, 1991). The presence of sustained protonactivated current in virtually all differentiated HD10.6 neurons, along with the ubiquitous expression of capsaicin-activated cur- rent in these cells, establishes the nociceptive phenotype of differentiated HD10.6 neurons.

Differentiated HD10.6 neurons also express $\alpha \beta$-methyleneATP-activated current. Cells that contain P2X1 or P2X3 receptors can respond to $\alpha \beta$-methylene-ATP (Collo et al., 1996). P2X1 receptors are present in sensory ganglia, the superior cervical ganglion, celiac ganglia, and spinal cord motoneurons (Valera et
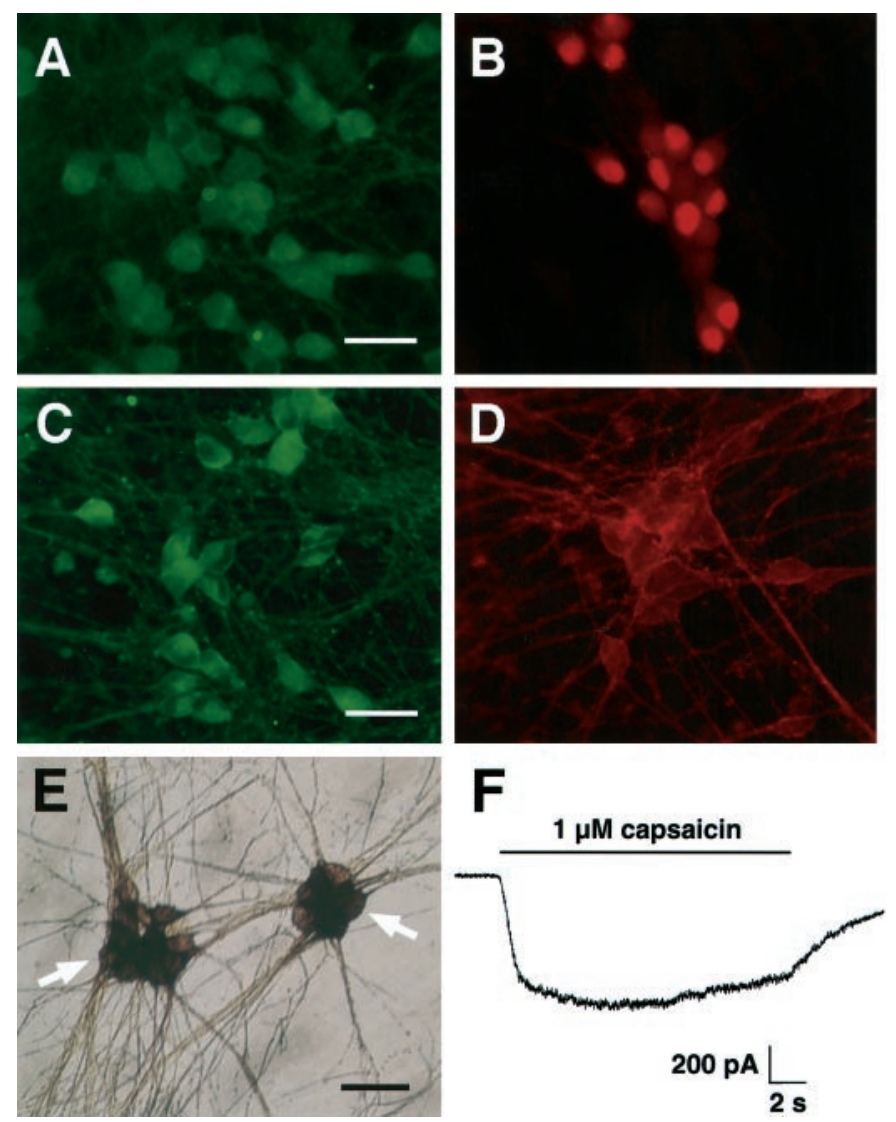

Figure 6. HD10.6 cells differentiate into neurons with nociceptive properties. $A-D$, Differentiated HD10.6 cells were immunoreactive for substance $\mathrm{P}(A)$, Islet-1 $(B)$, TrkA $(C)$, and p75 $(D)$. E, Capsaicin (1 $\mu \mathrm{M})$-induced cobalt uptake in differentiated HD10.6 cells is shown. $A r-$ rows indicate clusters of labeled cells. $F$, Electrophysiological recording of current elicited by applying $1 \mu \mathrm{M}$ capsaicin (solid horizontal bar) at a holding potential of $-80 \mathrm{mV}$ is shown. Scale bars: $A, B, 25 \mu \mathrm{m} ; C, D, 30$ $\mu \mathrm{m} ; E, 35 \mu \mathrm{m}$. 
al., 1994; Collo et al., 1996), whereas P2X3 receptors are expressed only in capsaicin-sensitive small-diameter sensory neurons (Chen et al., 1995). Therefore, the presence of $\alpha \beta$ methylene-ATP-activated currents in differentiated HD10.6 cells provides further evidence consistent with their nociceptive phenotype. Taken together, the presence of capsaicin-activated current, sustained proton-activated current, and $\alpha \beta$-methylene-ATPactivated current indicates that HD10.6 is a sensory neuronal line with nociceptive properties.

A property of nociceptors that differentiated HD10.6 neurons did not express was TTX-resistant sodium currents. The dissociation of TTX-resistant sodium channel expression from the expression of other nociceptive properties, such as capsaicin receptors, suggests that these properties are independently controlled by extrinsic cues. Clone HD10.6 provides a tool for studying the molecular mechanisms that differentially regulate these properties.

Before this study, there were no stable cell lines that mirror nociceptive sensory neurons. The sensory neuronal-like cell lines that had been described in the literature were established by fusion of postmitotic embryonic [F-11 cell line (Platika et al., 1985)] or neonatal [ND cell lines (Wood et al., 1990)] rat DRG neurons with mouse N18Tg2 neuroblastoma cells. These hybrid cell lines exhibit some DRG-selective properties, including transcription factors, cytoskeletal proteins, synaptic proteins, ion channels, neurotransmitters, and neurotransmitter receptors. However, tyrosine hydroxylase and neuropeptide Y immunoreactivities were expressed by the ND subclones (Suburo et al., 1992), suggesting that certain properties exhibited by these clones were derived from the neuroblastoma parent. In addition, these hybrid cell lines do not contain some of the neuropeptides (Suburo et al., 1992) normally present within sensory neuronal populations. Furthermore, low-threshold calcium current is a more predominant component of calcium current in differentiated hybrid cells (Boland and Dingledine, 1990; Kusano and Gainer, 1993; Kobrinsky et al., 1994) than in DRG neurons. Moreover, although capsaicin- and bradykinin-activated currents were expressed by a subset of F-11 cells at early passages, these cells lost the ability to express these properties after multiple passages (Kusano and Gainer, 1993).

The stable immortalized human PNS line described here can be expanded readily and then differentiated rapidly, providing a renewable and homogeneous source of sensory neurons. These neurons are functional and exhibit properties specific to subsets of sensory neurons, including characteristics unique to nociceptive sensory neurons. This immortalized human PNS line will be valuable for future studies of fundamental questions in developmental neurobiology, the identification and validation of novel drug targets, and the development and implementation of drug assays.

\section{REFERENCES}

Akopian AN, Sivilotti L, Wood JN (1996) A tetrodotoxin-resistant voltage-gated sodium channel expressed by sensory neurons. Nature 379:257-262

Bevan S, Szolcsanyi J (1990) Sensory neuron-specific actions of capsaicin: mechanisms and applications. Trends Pharmacol Sci 11:330-333.

Bevan S, Yeats J (1991) Protons activate a cation conductance in a sub-population of rat dorsal root ganglion neurones. J Physiol (Lond) 433:145-161.

Bevan SJ, James IF, Rang HP, Winter J, Wood JN (1987) The mechanism of action of capsaicin - a sensory neurotoxin. In: Neurotoxins and their pharmacological implications (Jenner P, ed), pp 261-277. New York: Raven.
Boland LM, Dingledine R (1990) Multiple components of both transient and sustained barium currents in a rat dorsal root ganglion cell line. J Physiol (Lond) 420:223-245.

Bronner-Fraser M, Fraser SE (1988) Cell lineage analysis reveals multipotency of some avian neural crest cells. Nature 335:161-164.

Caffrey JM, Eng DL, Black JA, Waxman SG, Kocsis JD (1992) Three types of sodium channels in adult rat dorsal root ganglion neurons. Brain Res 592:283-297.

Caterina MJ, Schumacher MA, Tominaga M, Rosen TA, Levine JD, Julius D (1997) The capsaicin receptor: a heat-activated ion channel in the pain pathway. Nature 389:816-824.

Chen CC, Akopian AN, Sivilotti L, Colquhoun D, Burnstock G, Wood JN (1995) A P2X purinoceptor expressed by a subset of sensory neurons. Nature 377:428-431.

Collo G, North RA, Kawashima E, Merlo-Pich E, Neidhart S, Suprenant A, Buell G (1996) Cloning of P2X5 and P2X6 receptors and the distribution and properties of an extended family of ATP-gated ion channels. J Neurosci 16:2495-2507.

Duff RS, Langtimm CJ, Richardson MK, Sieber-Blum M (1991) In vitro clonal analysis of progenitor cell patterns in dorsal root and sympathetic ganglia of the quail embryo. Dev Biol 147:451-459.

Elliott AA, Elliott JR (1993) Characterization of TTX-sensitive and TTX-resistant sodium currents in small cells from adult rat dorsal root ganglia. J Physiol (Lond) 463:39-56.

Fitzgerald M (1983) Capsaicin and sensory neurones-a review. Pain 15:109-130.

Frank E, Sanes JR (1991) Lineage of neurons and glia in chick dorsal root ganglia: analysis in vivo with a recombinant retrovirus. Development 111:895-908.

Holzer P (1988) Local effector functions of capsaicin-sensitive sensory nerve endings: involvement of tachykinins, calcitonin gene-related peptide and other neuropeptides. Neuroscience 24:739-768.

Hunt SP, Rossi J (1985) Peptide- and non-peptide-containing unmyelinated primary afferents: the parallel processing of nociceptive information. Philos Trans R Soc Lond [Biol] 308:283-289.

Kobrinsky EM, Pearson HA, Dolphin AC (1994) Low- and highvoltage-activated calcium channel currents and their modulation in the dorsal root ganglion cell line ND7-23. Neuroscience 58:539-552.

Kostyuk PG, Veselovsky NS, Tsyndrenko AY (1981) Ionic currents in the somatic membrane of rat dorsal root ganglion neurons-I. Sodium currents. Neuroscience 6:2423-2430.

Kusano K, Gainer H (1993) Modulation of voltage-activated Ca currents by pain-inducing agents in a dorsal root ganglion neuronal line, F-11. J Neurosci Res 34:158-169.

Le Douarin NM, Xue ZG, Smith J (1985) In vivo and in vitro studies on the segregation of autonomic and sensory cell lineages. J Physiol (Lond) 80:255-261

Lewis C, Neidhart S, Holy C, North RA, Buell G, Surprenant A (1995) Coexpression of $\mathrm{P} 2 \mathrm{X} 2$ and $\mathrm{P} 2 \mathrm{X} 3$ receptor subunits can account for ATP-gated currents in sensory neurons. Nature 377:432-435.

Lo L, Anderson DJ (1995) Postmigratory neural crest cells expressing c-RET display restricted developmental and proliferative capacities. Neuron 15:527-539.

Lo LC, Johnson JE, Wuenschell CW, Saito T, Anderson DJ (1991) Mammalian achaete-scute homolog 1 is transiently expressed by spatially restricted subsets of early neuroepithelial and neural crest cells. Genes Dev 5:1524-1537.

Matsumoto SG (1994) Neuronal differentiation in cultures of murine neural crest. II. Development of capsaicin-sensitive neurons. Brain Res Dev Brain Res 83:17-27.

Maxwell GD, Reid K, Elefanty A, Bartlett PF, Murphy M (1996) Glial cell line-derived neurotrophic factor promotes the development of adrenergic neurons in mouse neural crest cultures. Proc Natl Acad Sci USA 93:13274-13279.

Molliver DC, Radeke MJ, Feinstein SC, Snider WD (1995) Presence or absence of TrkA protein distinguishes subsets of small sensory neurons with unique cytochemical characteristics and dorsal horn projections. J Comp Neurol 361:404-416.

Molliver DC, Wright DE, Leitner ML, Parsadanian AS, Doster K, Wen D, Yan Q, Snider WD (1997) IB4-binding DRG neurons switch from NGF to GDNF dependence in early postnatal life. Neuron 19:849-861.

Ogata N, Tatebayashi H (1993) Kinetic analysis of two types of $\mathrm{Na}+$ channels in rat dorsal root ganglia. J Physiol (Lond) 466:9-37.

Pfaff SL, Mendelsohn M, Stewart CL, Edlund T, Jessell TM (1996) Requirement for LIM homeobox gene Isl1 in motor neuron generation 
reveals a motor neuron-dependent step in interneuron differentiation. Cell 84:309-320.

Platika D, Boulos MH, Baizer L, Fishman MC (1985) Neuronal traits of clonal cell lines derived by fusion of dorsal root ganglia neurons with neuroblastoma cells. Proc Natl Acad Sci USA 82:3499-3503.

Rao MS, Anderson DJ (1997) Immortalization and controlled in vitro differentiation of murine multipotent neural crest stem cells. J Neurobiol 32:722-746.

Roy ML, Narahashi T (1992) Differential properties of tetrodotoxinsensitive and tetrodotoxin-resistant sodium channels in rat dorsal root ganglion neurons. J Neurosci 12:2104-2111.

Sah DW, Ray J, Gage FH (1997) Bipotent progenitor cell lines from the human CNS. Nat Biotechnol 15:574-580.

Saito T, Greenwood A, Sun Q, Anderson DJ (1995) Identification by differential RT-PCR of a novel paired homeodomain protein specifically expressed in sensory neurons and a subset of their CNS targets. Mol Cell Neurosci 6:280-292.

Sangameswaran L, Delgado SG, Fish LM, Koch BD, Jakeman LB, Stewart GR, Sze P, Hunter JC, Eglen RM, Herman RC (1996) Structure and function of a novel voltage-gated, tetrodotoxin-resistant sodium channel specific to sensory neurons. J Biol Chem 271:5953-5956.

Schweizer G, Ayer-Le Lievre C, Le Douarin NM (1983) Restrictions of developmental capacities in the dorsal root ganglia during the course of development. Cell Differ 13:191-200.

Shah NM, Marchionni MA, Isaacs I, Stroobant P, Anderson DJ (1994) Glial growth factor restricts mammalian neural crest stem cells to a glial fate. Cell 77:349-360.

Shah NM, Groves AK, Anderson DJ (1996) Alternative neural crest cell fates are instructively promoted by TGFbeta superfamily members. Cell 85:331-343.

Stemple DL, Anderson DJ (1992) Isolation of a stem cell for neurons and glia from the mammalian neural crest. Cell 71:973-985.

Suburo AM, Wheatley SC, Horn DA, Gibson SJ, Jahn R, Fischer-Colbrie R, Wood JN, Latchman DS, Polak JM (1992) Intracellular redistribution of neuropeptides and secretory proteins during differentiation of neuronal cell lines. Neuroscience 46:881-889.
Sun Y, Maxwell GD (1994) Ciliary neurotrophic factor (CNTF) has a dose-dependent biphasic effect on the number of adrenergic cells which develop in avian trunk neural crest cultures. Neurosci Lett 165:1-4.

Szallasi A (1994) The vanilloid (capsaicin) receptor: receptor types and species differences. Gen Pharmacol 25:223-243.

Valera S, Hussy N, Evans RJ, Adami N, North RA, Suprenant A, Buell G (1994) A new class of ligand-gated ion channel defined by P2X receptor for extracellular ATP. Nature 371:516-519.

Varley JE, Maxwell GD (1996) BMP-2 and BMP-4, but not BMP-6, increase the number of adrenergic cells which develop in quail trunk neural crest cultures. Exp Neurol 140:84-94.

Waldmann R, Champigny G, Bassilana F, Heurteaux C, Lazdunski M (1997a) A proton-gated cation channel involved in acid-sensing. Nature 386:173-177.

Waldmann R, Bassilana F, de Weille J, Champigny G, Heurteaux C, Lazdunski M (1997b) Molecular cloning of a non-inactivating protongated $\mathrm{Na}+$ channel specific for sensory neurons. J Biol Chem 272:20975-20978.

Wood JN, Winter J, James IF, Rang HP, Yeats J, Bevan S (1988) Capsaicin-induced ion fluxes in dorsal root ganglion cells in culture. J Neurosci 8:3208-3220.

Wood JN, Bevan SJ, Coote PR, Dunn PM, Harmar A, Hogan P, Latchman DS, Morrison C, Rougon G, Theveniau M, Wheatley S (1990) Novel cell lines display properties of nociceptive sensory neurons. Proc R Soc Lond [Biol] 241:187-194.

Xue ZG, Le Douarin NM, Smith J (1988) Insulin and insulin-like growth factor-I can trigger the differentiation of catecholaminergic precursors in cultures of dorsal root ganglia. Cell Differ Dev 25:1-10.

Xue ZG, Xue XJ, Fauquet M, Smith J, Le Douarin N (1992) Expression of the gene encoding tyrosine hydroxylase in a subpopulation of quail dorsal root ganglion cells cultured in the presence of insulin or chick embryo extract. Brain Res Dev Brain Res 69:23-30.

Zeilhofer HU, Swandulla D, Reeh PW, Kress M (1996) Ca2+ permeability of the sustained proton-induced cation current in adult rat dorsal root ganglion neurons. J Neurophysiol 76:2834-2840. 